\title{
Now You See Him, Now You Don't: Anthropomorphic Representations of the Hittite Kings
}

\author{
Müge Durusu-TANriöVer, Bilkent University*
}

\section{Introduction}

Hittite kings lived as mortals and became deified only after death. Beyond mere flesh and blood, the identities of the kings were encapsulated in their office, title, and the idea of kingship. Their representations were also divergent, ranging from figural renderings of royal bodies to the writing of names and titles in hieroglyphic Luwian, ${ }^{1}$ mainly on rock reliefs and seals. Starting with the 14 th century BC, ${ }^{2}$ anthropomorphic

\footnotetext{
* Acknowledgements: I am grateful to Trevor Bryce for his comments on an earlier draft, particularly drawing my attention to the Emirgazi altars. I am particularly thankful to the five anonymous referees for their close reading of the manuscript and their comments. I would like to thank John F. Cherry, Andrew Dufton, N. İlgi Gerçek, Claudia Glatz, Linda Gosner, Ömür Harmanşah, Katherine Harrington, Kathryn McBride, M. Willis Monroe, and Felipe Rojas for offering insightful comments on various drafts.

${ }^{1}$ Luwian is an Indo-European language closely related to Hittite, written mainly with the hieroglyphic script, while a small cuneiform Luwian corpus also exists, as compiled by H. Otten, Luvische Texte in Umschrift (Berlin, 1953); and F. Starke, Die keilschriftluwischen Texte in Umschrift, Studien zu den Boğazköy-Texten 30 (Wiesbaden, 1985).

${ }^{2}$ A group of relief vases dating to the 16th century BC, such as the well-known Inandık vase, might also include anthropomorphic depictions of the king. However, as recently argued by A. Schachner, these early examples depict the king in an anonymous manner: while he is leading cult performance, he is not differenti-
}

representations of Hittite kings ${ }^{3}$ were incorporated into a very small corpus dominated by seals and rock reliefs, with the name of the king often accompanying the image. Similarly, royal names and epithets in the hieroglyphic script started in the Hittite Old Kingdom with the reign of Tudhaliya I/II (early 14th century $\mathrm{BC})^{4}$ and were standard features of reliefs and seals in the 14 th-13th centuries, ${ }^{5}$ as represented by numerous

ated through iconography or text; see A. Schachner, "Gedanken zur Datierung, Entwicklung und Funktion der hethitischen Kunst," AoF 39/1 (2012): 136. In this paper, however, I focus on anthropomorphic representations in which we can securely identify Hittite kings, through hieroglyphic labels, cuneiform inscriptions (exclusively on seals), and/or by iconographic details. Since such depictions are almost exclusively from the 14th and 13th centuries $\mathrm{BC}$ (with the possible exception of Alaca Höyük, cf. n. 58 below), my arguments here also mostly concern these two centuries.

${ }^{3}$ My analysis in this paper concerns the Hittite "Great King," i.e., the king who ruled from the imperial capital at Hattuša between ca. 1650-1180 BC (except for a brief period when the capital was moved to Tarhuntašš by Muwatalli II) and used the title of "Great King" (Lugal.GaL). We know of twenty-seven or twenty-eight such individuals, although an absolute chronology of their reigns is still in flux.

${ }^{4}$ J. D. Hawkins, "Scripts and Texts," in The Luwians, Handbuch der Orientalistik 86, ed. C. H. Melchert (Leiden, 2003), 166.

${ }^{5}$ A. Payne, Hieroglyphic Luwian: An Introduction with Original Texts (Wiesbaden, 2010), 2. The seals mentioned here belong to the "aedicula type," and depict the name of the ruler as flanked 
examples. The pervasiveness of hieroglyphic Luwian is visible in the fact that almost all the preserved anthropomorphic representations contain a hieroglyphic element, while there are many more inscriptions which are not accompanied by figural imagery. As such, the written and the anthropomorphic illustrations of the Hittite kings represent a contrast in terms of quantity: royal names and titles in the hieroglyphic script were liberally used, while anthropomorphic depictions were reserved for select examples. ${ }^{6}$

In this article, I argue that the adoption of anthropomorphic representations by Hittite kings were a selective phenomenon. Signifying power and presence through rendering royal titles in hieroglyphic Luwian signs flanking individual names was a conscious preference to visually emphasize the office of kingship more than the individual kings. Starting with the 14th century BC, however, Hittite kings started commissioning anthropomorphic representations explicitly identifying themselves, and continued this practice until the fall of the empire at the start of the 12th century $\mathrm{BC}$. The reign of Muwatalli II in the early 13th century was the most active period of royal patronage of anthropomorphic illustrations executed on seals and rock reliefs. The triggers for the accelerated use of this iconography in the 13th century, I suggest, rested mainly on two phenomena. First, Hatti was under a lot of pressure from the borderlands of the empire as well as the neighboring states. Second, the royal succession in Hattuša was rife with conflict, disrupting the continuity of kingship, and forcing the rulers to emphasize their individual re-

by hieroglyphic Luwian signs, topped with a winged sun-disc, surrounded by a cuneiform inscription: J. Seeher, "Der Landschaft Sein Siegel Aufdrücken: Hethitische Felsbilder und Hieroglypheninschriften als Ausdruck Des Herrscherlichen Macht- und Territorialanspruchs," AoF 36/1 (2009): 127; S. Herbordt, "The Bulls on the Seals of Muwatalli II," in ipamati kistamati pari tumatimis: Luwian and Hittite Studies Presented to J. David Hawkins on the Occasion of His 70th Birthday, ed. I. Singer (Tel Aviv, 2010), 123.

${ }^{6} \mathrm{P}$. Goedegebuure argued that the low number of royal images in Hittite art, often in seemingly unfinished condition, was related to iconoclasm, building on the specific relationship theorized by the Hittites to be present between images and their referents. While this was not a fear of iconoclasm that could harm the physical body of the referent (as was the case in Mesopotamia), the images were still seen as portals to the people and the gods they were depicting and could be used to disempower them. P. M. Goedegebuure, "Hittite Iconoclasm: Disconnecting the Icon, Disempowering the Referent," in Iconoclasm and Text Destruction in the Ancient Near East and Beyond, Oriental Institute Seminars 8, ed. N. N. May (Chicago, 2012), 409, 423-24. lationships with the divine realm as legitimate kings. In an attempt to articulate the power bestowed upon them by gods as legitimate and able rulers, the Hittite kings started to commission more anthropomorphic depictions of themselves, albeit scrupulously. ${ }^{7}$ In these figural royal representations, the connection between the anthropomorphic manifestations and divinity was emphasized and reinforced. The king's body was depicted in only three ways: when he was facing a deity; when he was in the protective embrace of a god; or when the king was a god himself. Thus, in all the examples I discuss below, the manifestation of the king in human form is conditioned by his absorption by, and encounter with, divine energy. ${ }^{8}$ In other words, a divine element (either a god or a deified king) was a mandatory prerogative for the depiction of the body of the Hittite king.

Contrary to other Near Eastern traditions of representing kingship in a culturally-coded way signifying both the king and his office at the same time, ${ }^{9}$ specific

${ }^{7}$ M. E. Balza and C. Mora demonstrate that an upward trend was visible in the use of hieroglyphic Luwian inscriptions as they became the preferred mode of royal propaganda in the second half of the 13th century BC. They argue that later Hittite kings utilized monumental inscriptions highlighting their religious legitimacy in the absence of political legitimacy ("'And I Built This Everlasting Peak for Him': The Two Scribal Traditions of the Hittites and the NA 4 bekur SAG.UŠ," AoF 38/2 (2011): 216-18.

${ }^{8}$ S. de Martino, "Symbols of Power in the Late Hittite Kingdom," in Pax Hethetica (FS Singer), ed. Y. Cohen et al. StBoT 51 (Wiesbaden, 2010), 88-89, also suggests that royal iconography was specifically geared towards emphasizing close and privileged relationships between the kings and the gods, particularly during the reign of Muwatalli II.

${ }^{9}$ A good example is the Neo-Assyrian Empire, the kings of which frequently commissioned landscape monuments in the borderlands and complex relief programs in capital cities during the 9th-7th centuries BC. In both cases, Neo-Assyrian royal representation depicted kingship rather than the king himself. Textual sources describe the images on monuments as șalmu sarrütiya "the image of (my) kingship." The salmu of the king was not intended to be a literal and precise physical representation of a person, but was rather a "conventionally coded, culturally mediated, idealized representation" of kingship, as defined by Zainab Bahrani, The Graven Image: Representation in Babylonia and Assyria (Philadelphia, 2003), 123, 135, drawing from Irene Winter's work. See also A. Shafer, "Assyrian Royal Monuments on the Periphery: Ritual and the Making of Imperial Space," in Ancient Near Eastern Art in Context: Studies in Honor of Irene J. Winter by Her Students, ed. J. Cheng and M. H. Feldman (Leiden, 2007), 136-37; I. J. Winter, "The Body of the Able Ruler: Toward an Understanding of the Statues of Gudea," in Dumu-É-dub-ba-a: Studies in Honor of A. W. Sjöberg, ed. H. Behrens et al. (Philadelphia, 1989); I. J. Winter, "'Idols of the King': Royal Images as Recipients of Ritual Action in Ancient 
depictions of both kingship and individual kings were both sought after in the Hittite examples. The hieroglyphic signs for Great King (MAGNUS.REX) ${ }^{10}$ often doubled with the winged sun disc positioned above the name of the king, emphasized the importance of the office of kingship as a continuous institution. In contrast, anthropomorphic representations intended to articulate the relationship of the individual king with the divine realm and emphasized his right to rule as the king supported by the gods. In comparison with other eastern Mediterranean traditions, especially the Neo-Assyrian and Egyptian examples, anthropomorphic representations of Hittite kings are conservative in terms of both quantity and content. The few images of the Hittite kings depict them either facing, pouring libations to, or being in the embrace of a god; or deified themselves. ${ }^{11}$ The body of the king in Hittite iconography, therefore, was visible only when he was in contact with the divine realm, as if the body of the king was a culmination of divine energy.

\section{Representations of the Names and Titles of Hittite Kings}

Exploring the non-anthropomorphic representations of Hittite kings necessitates a detour into hieroglyphic Luwian, a distinctly Anatolian writing system developed to render an Anatolian language related to Hittite. Different opinions exist as to the motivations

Mesopotamia" Journal of Ritual Studies 6/1 (1992); I. J. Winter, "Art in Empire: The Royal Image and the Visual Dimensions of Assyrian Ideology" in Assyria 1995: Proceedings of the 10th Anniversary Symposium of the Neo-Assyrian Text Corpus Project, Helsinki, September 7-11, 1995, ed. S. Porpola and R. Whiting (Helsinki, 1997), 359-81. These images carried a part of the king's agency to the borderlands of the empire, through the performative act of carving an image of kingship in stone: Ö. Harmanşah, "Source of the Tigris: Event, Place and Performance in the Assyrian Landscapes of the Early Iron Age," Archaeological Dialogues 14/2 (2007): 181.

${ }^{10}$ In transliterating Luwian, I follow the standard practice of using Latin words corresponding with the meanings of the hieroglyphic signs.

${ }^{11}$ Texts dealing with royal mortuary ritual often refer to the death of a member of the royal family as "when he/she became a god," as exemplified by the opening sentences of the ritual text: "When in Hattuša a great loss occurs, (that is), either the king or queen becomes a god, all, big and small, take away their reeds/ straws and start to wail": T. van den Hout, "Death as a Privilege: The Hittite Royal Funerary Ritual," in Hidden Futures: Death and Immortality in Ancient Egypt, Anatolia, the Classical, Biblical and Arabic-Islamic World, ed. J. M. Bremer, T. van den Hout, and R. Peters (Amsterdam, 1994), 59. behind and the chronology of the invention of this script. J. D. Hawkins argues that Luwian hieroglyphs were an indigenous development in second millennium western Anatolia, with possible influence from the Aegean, as opposed to the cuneiform script that was adopted from Mesopotamia. ${ }^{12}$ Similarly, W. Waal suggests that the hieroglyphic script emerged at the turn of the second millennium $\mathrm{BC}$ and was already in use in Old Assyrian Kültepe, where it might have been used to inscribe the ișrtum-documents detailing transactions between Assyrian merchants and Anatolian parties, including the palace. ${ }^{13} \mathrm{I}$. Yakubovich argues that the development of the script took place in Hattuša around c. 1400 BC, when the city had a thriving population of Hittite and Luwian groups seeking to develop a shared script to inscribe durable objects with. He suggests this to be a "nationalistic" gesture trying to break ties with the Mesopotamian cuneiform. ${ }^{14}$ M. E. Balza and C. Mora see the accelerated use of hieroglyphic Luwian as a response to the need of the Hittite kings of the 13th century BC to present their legitimacy to higher numbers of people than would be possible with the cuneiform script. ${ }^{15}$ M. Marazzi, in the same vein, has suggested that the strong iconic character of Anatolian hieroglyphs were a reflection of the complex and multi-lingual Hittite society, where the signs could act independent of languages. ${ }^{16}$

While the chronology of and the motivations for the emergence of the script might be a point of debate, it is commonly accepted that Luwian has a long history as a spoken language. Along with Palaic and Hittite, Luwian is one of the Indo-European languages that appear in Anatolia in the 3rd millennium BC. ${ }^{17}$ Hittite laws indicate that "Luwiya" was a geographical, social and cultural attestation. Specific legal treatments

12 J. D. Hawkins, "Writing in Anatolia: Imported and Indigenous Systems," World Archaeology 17/3 (1986): 373-74.

${ }^{13}$ W. Waal, "Writing in Anatolia: The Origins of the Anatolian Hieroglyphs and the Introductions of the Cuneiform Script," AoF 39/2 (2012): 287-315.

${ }^{14}$ I. S. Yakubovich, "Hittite-Luvian Bilingualism and the Development of Anatolian Hieroglyphs," Acta Linguistica Petropolitana 4/1 (2008): 28-29.

${ }^{15}$ Balza and Mora, “'And I Built This Everlasting Peak for Him'”: 217.

${ }^{16}$ M. Marazzi, Il Geroglifico Anatolico: Problemi di Analisi e Prospettive di Ricerca (Rome, 1990); M. Marazzi "Scrittura, Percezione e Cultura: Qualche Riflessione sull'Anatolia in età hittita," Kaskal7 (2010): 219.

${ }^{17}$ T. Bryce, The Kingdom of the Hittites (Oxford, 2005), 11. 
would take place when a Luwian and a Hittite came into conflict, suggesting that Hittite and Luwian populations were both close and distinct enough to warrant differentiated judicial process. ${ }^{18}$ While "Luwiya" cannot be located precisely in Anatolian geography, and probably shifted its borders with the Hittite heartland over time, assuming it contained considerable portions of western, southwestern, and southern Anatolia remains the most plausible scholarly opinion. ${ }^{19}$ The appearance of hieroglyphic Luwian monuments in Hattuša itself (NișANTAŞ and SÜDBURG) also speak to the fact that the hieroglyphic script and the Luwian language were important players in the center of the empire, probably related to a dominant Luwian population. ${ }^{20}$ As such, Luwian can be seen as the language of the borderlands of the empire, ${ }^{21}$ which gradually took hold in the capital and the center, demanding that the Hittite kings adopt this specific means of communication for their statements of power. ${ }^{22}$ Once adopted, Hieroglyphic Luwian became an indispensable tool for Hittite royalty in the 13th century BC, significantly challenging the ways in which Hittite history was recorded and related. ${ }^{23}$ With this change in the

${ }^{18}$ C. H. Melchert, "Introduction," in The Luwians, HdO 86, ed. C. H. Melchert (Leiden, 2003), 1-2.

${ }^{19}$ The Neo-Hittite version of the Hittite laws replaces "Luwiya" with "Arzawa," a western Anatolian polity whose exact location and territory remain unknown, but nevertheless supply a western anchor for Luwiya: ibid, 2. The close parallels between Luwian and Iron Age Lycian, coupled with the close relationship between Luwian ritual texts found in Hattuša and Kizzuwatna, suggest a southern and southwestern Anatolian location for Luwiya: C. H. Melchert, "The Language" in Luwians, ed. Melchert, 173-77 (contra I. Yakubovich, who sees Luwiya as mostly centered around the Konya plain, with a possible extension into the Sakarya basin: I. Yakubovich, The Socio-Linguistics of the Luvian Language, (Leiden, 2010), 242-48). While these details establish a patchy network of evidence for providing a precise location for Luwiya, they are suggestive of a considerable part of Anatolia speaking the Luwian language.

${ }^{20}$ I. Yakubovich, "Luwian and the Luwians," in The Oxford Handbook of Ancient Anatolia, 10,000-323 BCE, ed. S. R. Steadman and G. McMahon (Oxford, 2010), 535.

${ }^{21}$ Ö. Harmanşah, Place, Memory and Healing: An Archaeology of Anatolian Rock Monuments (New York, 2015), 6.

22 "Borderlands" in the sense that I use them here are not passively peripheral regions of the empire, but its constituent parts along the borders, where Hittite identities co-existed with other, local self-definitions. This understanding draws from postcolonial literature, and is inspired by Homi Bhabha's understanding of the "Third Space," where two or more cultures overlap: H. Bhabha, The Location of Culture (London, 2004), 56.

${ }^{23}$ Balza and Mora suggest that Hieroglyphic Luwian replaced the earlier tradition of composing Annals in the cuneiform script in

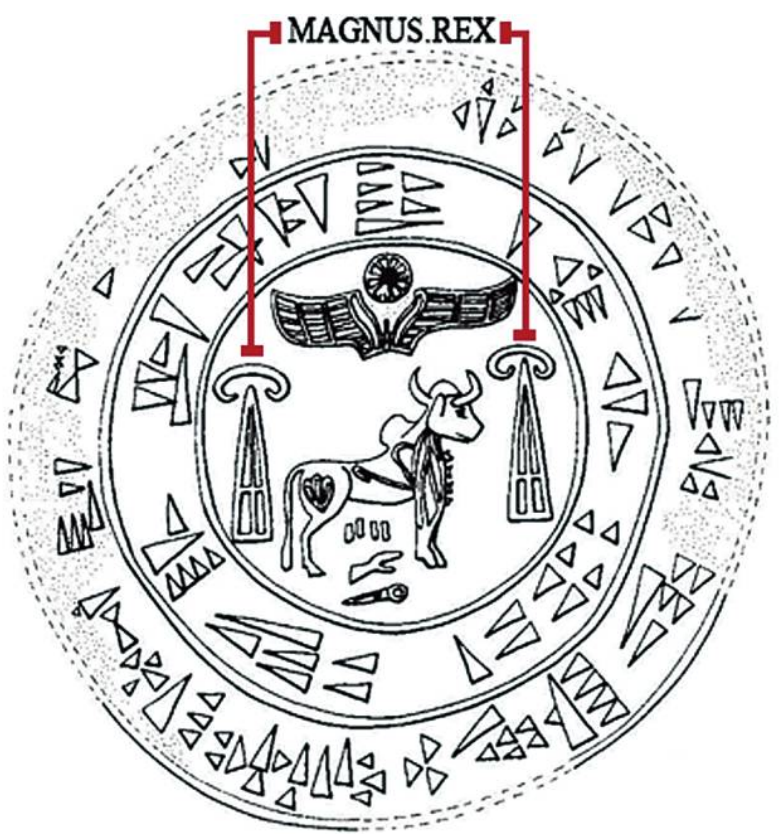

Figure 1-Stamp seal of Muwatalli II with the hieroglyphic Luwian writing of his name. The MAGNUS.REX signs are marked for added clarity (Herbordt, Bawanypeck, and Hawkins, Die Siegel der Grosskönige und Grossköniginnen, Cat. Rek. 37.1-4, Tafel 7. Copyright Archive of the Boğazköy-Expedition, DAI Berlin). Image courtesy of Suzanne Herbordt.

last century of the empire, it can be speculated that imperial history was disseminated to a wider audience, both through the high-level of visual recognition the script enables in comparison to cuneiform, thus leading to a better inclusion of the illiterate in the mechanics of the empire, ${ }^{24}$ and through the open-air context of the Hieroglyphic Luwian inscriptions, as opposed to the cuneiform texts preserved in royal archives.

The hieroglyphic writing system offered figural alternatives to bodily representations of Hittite kings on both seals and reliefs, exemplified by a seal of $\mathrm{Mu}-$ watalli II (Figure 1). It contains the standard formula for most Hittite royal stamp seals: a cuneiform ring surrounding hieroglyphic Luwian characters spelling out the titles and the name(s) of the king, MAGNus. REX BOS $2 . M I-t a ̀-l i$, “Great King Muwatalli." The outer rings in cuneiform read: "The seal of Muwatalli, Great

the second half of the 13th century BC: Balza and Mora, "'And I Built This Everlasting Peak for Him'": 216-17.

${ }^{24}$ On the "superlinguistic" power of hieroglyphic signs that could enable communication without necessarily being able to read a particular language, cf. Marazzi, Il Geroglifico Anatolico: Problemi di Analisi e Prospettive di Ricerca; Balza and Mora, "And I Built This Everlasting Peak for Him'": 220. 
King, King of the Land of Hatti, dear to the. . . God, Son of Muršili, Great King, Hero.” ${ }^{25}$ Both the center and the outer rings thus have documentary purposes, clearly situating Muwatalli II within the genealogy of Hittite kingship and supplying his full name and title.

The writing of the name of the king, $\mathrm{BOS}_{2} \cdot M I-t \grave{a}-$ $l i$, needs deeper exploration. The sign $\mathrm{BOS}_{2} \cdot M I$, often depicted as the head of a bull, has the mu reading, and is thus the first syllable of the king's name. ${ }^{26}$ In this particular example, the whole bull is depicted as flanked by two MAGNUS.REX signs as opposed to just the head of the animal. ${ }^{27}$ The seal, therefore, does not contain any anthropomorphic representation of either the deity or the king, but the central use of the hieroglyphic signs imposes the presence of the Storm God through his sacred animal. ${ }^{28}$ In the same vein, the emphasized signs for Great King (MAGNUS.REX) can be read as referring to the office of kingship. In this and other royal seals, the MAGNUS.REX signs are almost always larger than the individual signs making up the king's name, occupy more space than the royal name, and are repeated to multiply their effect. ${ }^{29}$ Kingship is thus emphasized above the individual identity of the king.

The flexibility of the hieroglyphic writing system offered a venue for playing with and replacing anthropomorphic representations. It is possible to suggest that an emphasized use of the MAGNUS.REX ("Great King") sign developed an iconographic quality that would be recognizable as "kingship." As such, the MAGNUS.REX signs in these seals are clear visual counterparts to the depiction of the deity they accompany, and evident graphic markers of the office of kingship.

If we take the Luwian signs for writing MAGNUS.REX as a means of a figural (albeit non-anthropomorphic)

${ }^{25}$ S. Herbordt, D. Bawanypeck, and J. D. Hawkins, Die Siegel der Grosskönige und Grossköniginnen auf Tonbullen aus dem Nisantepe-Archiv in Hattusa (Darmstadt, 2011), 124, Cat. No. 37.

${ }^{26}$ Payne, Hieroglyphic Luwian: An Introduction with Original Texts, 169, sign *107.

${ }^{27}$ Ibid, 162, sign * 18 .

${ }^{28}$ Güterbock, Siegel aus Boğasköy II, 46; Herbordt, “The Bulls on the Seals of Muwatalli II," 126.

${ }^{29}$ These observations pertain only to the seals of kings, and do not apply to seals shared by the king and the queen. An example for the latter is the seal of Hattušili III and Puduhepa, where the names of the royal couple are flanked by the MAGNUS.REX (king) and MAGNUS.DOMINA (queen) signs on either side of the centerpiece, as opposed to the repetition of the MAGNUS.Rex: Herbordt, Bawanypeck, and Hawkins, Die Siegel der Grosskönige und Grossköniginnen, 168-78, Cat. Nos. 70-80, Tafeln 27-31. representation of Hittite kingship, we end up with a far more abundantly utilized tradition of visually depicting Hittite royalty than anthropomorphic imagery. Many seal impressions and inscriptions bypass anthropomorphic representations, and still signal the existence of gods and kings through the flexibility of the hieroglyphic writing system, turning the MAGNUS. REX signs into an emblem for the office of kingship. This quality of hieroglyphics is an important example of how writing systems can interplay with, or even replace, anthropomorphic representations. The signs were able to overcome limitations of literacy, which was a power that the cuneiform script did not have. Hieroglyphic Luwian was able to communicate, continuously, an office of kingship occupied by varied individuals. By using the MAGNUS.REX signs consistently when the signs for writing the royal name would change with each king, hieroglyphic Luwian would convey royal presence even to illiterate citizens without the figure of the king. Anthropomorphic depictions of the Hittite king, on the other hand, visually encoded the close relationship between the specific ruler and the divine realm, which made them convenient tools of communication in times of crisis. I now turn to these examples.

\section{Anthropomorphic Representations of the Hittite King}

Figural representations of the human form appear on a wide variety of media in Hittite art: orthostats, gate sculptures, wall paintings, rock reliefs, large-scale freestanding statues, metal statuettes, relief vases, metal vessels, figurines, and glyptic art. ${ }^{30}$ In this wide array, most representations belong to gods and goddesses, and they are encountered on all the above-mentioned media. Ordinary people, priests, and court officials, mostly in ritual settings, are also depicted on various artifacts and monuments. A focus on objects and monuments with figures that can be securely identified as a Hittite Great King, however, narrows down the study to rock reliefs, orthostats, ceremonial metal vessels, and seals and their impressions.

These diverse media of the preserved anthropomorphic representations of the Hittite king imply varied

${ }^{30}$ A. Özyar, "A Prospectus of Hittite Art Based on the State of Our Knowledge at the Beginning of the 3rd Millennium AD," in Structuring and Dating in Hittite Archaeology: Requirements Problems - New Approaches, Byzas 4, ed. D. P. Mielke, U.-D. Schoop and J. Seeher (Istanbul, 2006), 125-48. 


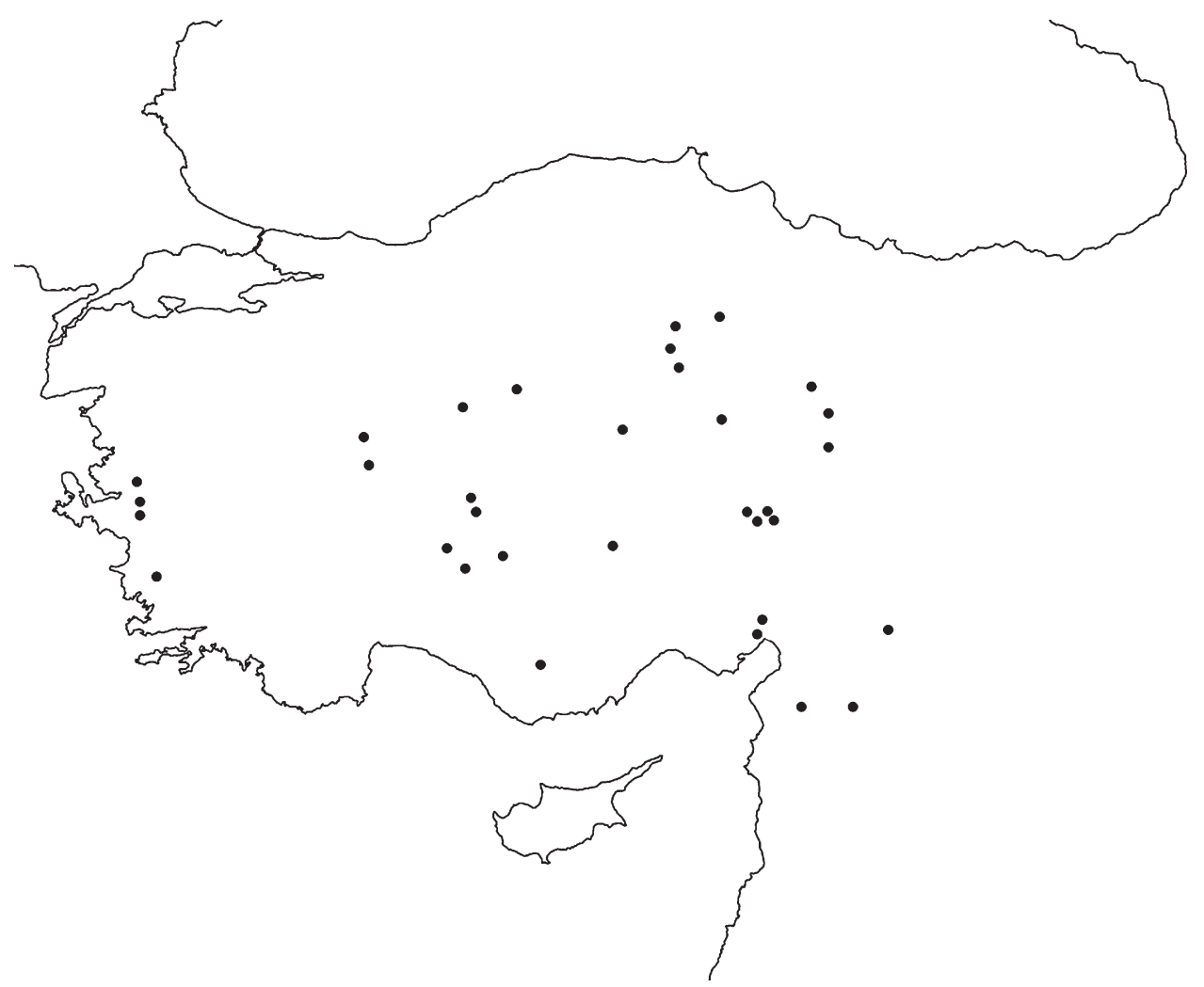

Figure 2-Landscape monuments of Late Bronze Age Anatolia and northern Syria (map by author).

audiences and mobility patterns. As the immobile objects in this corpus, rock reliefs and orthostats are the only ones for which we can analyze the intended long-term contexts and locations. ${ }^{31}$ An exploration of Late Bronze Age imagery on rock surfaces in Anatolia reveals a distribution throughout the empire, emphasizing the roles that the borderlands played in the execution of this phenomenon (Figure 2). On the one hand, many of these monuments are situated in locations difficult to access and see in the rural landscape, making one question whether or not they were intended to mark territorial control and power. ${ }^{32}$ Rather, they can be read as performances of place-making,

\footnotetext{
${ }^{31}$ I use the term "orthostat" to refer to quarried stone slabs incorporated into edifices, and "rock relief" to designate images carved on living rock surfaces in the open landscape.

${ }^{32}$ Some scholars have argued that Hittite landscape monuments were agents of negotiation for territorial control. For a recent and elegant model, see C. Glatz and A. M. Plourde, "Landscape Monuments and Political Competition in Late Bronze Age Anatolia: An Investigation of Costly Signaling Theory," BASOR 361 (2011): 33-66. In partial agreement, Stokkel argued for two functions fulfilled by rock monuments: a ceremonial one, in which the reliefs are not easily visible, and a landmark one, in which the reliefs have
}

as recently argued by Ö. Harmanşah. ${ }^{33}$ On the other hand, seals and metal vessels are mobile, ${ }^{34}$ and while considering their value(s) and function(s), we can be fairly certain that they were intended to travel through royal households, elite circles, and administrative offices of the Hittite empire, vassal kingdoms, and neighboring states. As such, their imagery would have circulated between the administrative elites in Hattuša and their counterparts throughout the empire and beyond, making them visible to a select audience in the center and the borderlands.

much larger viewsheds: P. J. A. Stokkel, "A New Perspective on Hittite Rock Reliefs," Anatolica 31 (2005): 174-75, 177.

${ }^{33}$ Ömür Harmanşah argues that Hittite rock reliefs erected to mark significant areas in the local landscape, such as springs, gorges, or passes; see, for example, his "Figures Carved on the Living Rock: Hittite Rock Monuments," in Hittites: An Anatolian Empire, ed. M. Doğan-Alparslan and M. Alparslan (İstanbul, 2013), 567, and Place, Memory and Healing, 33.

${ }^{34}$ So far, there is only one metal vessel securely identified to be a Hittite king (i.e., the "Silver Vessel in the Form of a Fist," MFA 2004.2230), and the following claims in this paragraph apply mainly to seals. 
The items in this corpus consisting of orthostats, rock reliefs, metal vessels, seals and their impressions present several challenges related to their differing scales, contexts, materials, and whether or not they included any writing, which can make their comparison a daunting task. As a result, studies of each medium have been compartmentalized and isolated from each other. Comprehensive studies exist for the entire range of rock reliefs ${ }^{35}$ and seals, ${ }^{36}$ while metal vessels have usually been published as individual pieces or as hoards. ${ }^{37}$ Eclectic studies of Hittite art, looking at materials beyond one single corpus, remain less conventional. ${ }^{38}$ Looking across these media themati-

${ }^{35}$ See, for example, I. J. Gelb, Hittite Hieroglyphic Monuments (Chicago, 1939); K. Kohlmeyer, "Felsbilder der Hethitischen Großreichzeit" Acta Praehistorica et Archaeologica 15 (1983): 7-135; K. Bittel, Denkmäler eines hethitischen Großkönigs des 13. Jahrbunderts von Christus (Düsseldorf, 1984); H. Ehringhaus, Götter, Herrscher, Inschriften: Die Felsreliefs der Hethitischen Großreichszeit in der Türkei (Mainz am Rhein, 2005); Glatz and Plourde, "Landscape Monuments," 33-66; Ö. Harmanşah, Place, Memory, and Healing.

${ }^{36}$ See, for example, H. G. Güterbock, Siegel aus Boğasköy I (Berlin, 1940); H. G. Güterbock, Siegel aus Boğasköy II (Berlin, 1942); T. Beran, Die Hethitische Glyptik von Boğazköy I. Teil: Die Siegel und Siegelabdrücke der Vor-und Althethitischen Perioden und die Siegel der Hethitischen Grosskönige (Berlin, 1967); H. G. Güterbock, "Seals and Sealing in Hittite Lands," in From Athens to Gordion: The Papers of a Memorial Symposium for Rodney S. Young, ed. Keith DeVries (Philedelphia, 1980), 51-63; R. M. Boehmer and H. G. Güterbock, Die Glyptik von Boğazköy: Grabungskampagnen 1931-1939, 1952-1978. Glyptik aus dem Stadtbegiet von Boğazköy. II. Teil (Berlin, 1987); C. Mora, La Glittica Anatolica Del Ii Millennio A.C.: Classificazione Tipologica (Pavia, 1987); S. P. Lumsden, Symbols of Power: Hittite Royal Iconography in Seals, (Ph.D. diss., University of California, Berkeley, 1990); D. Beyer, Emar IV: Les Sceaux (Fribourg, 2001); S. Herbordt, "Hittite Glyptic: A Reassessment in the Light of Recent Discoveries," in Structuring and Dating in Hittite Archaeology ed. Mielke, Schoop, and Seeher, 95-108; Herbordt, Bawanypeck, and Hawkins, Die Siegel der Grosskönige und Grossöniginnen.

${ }^{37}$ See, for example, K. Emre and A. Çınaroğlu, "A Group of Metal Hittite Vessels from Kunı - Kastamonu," in Aspects of Art and Iconography: Anatolia and Its Neighbors: Studies in Honor of Nimet Özgüç, ed. M. J. Mellink, E. Porada and T. Özgüç (Ankara, 1993), 675-713. H. G. Güterbock and T. Kendall, "A Hittite Silver Vessel in the Form of a Fist," in The Ages of Homer: A Tribute to Emily Townsend Vermenle, ed. J. B. Carter and S. P. Morris (Austin, 1995), 45-60.

${ }^{38}$ E.g., E. Akurgal, Die Kunst der Hethiter (Munich, 1961); K. Bittel, Die Hethiter. Die Kunst Anatoliens vom Ende des 3. bis zum Anfang des 1. Jahrtausends von Christus (Munich, 1976); M. A. Darga, Hitit Sanatı (İstanbul, 1992); T. Özgüç, "Studies on Hittite Relief Vases, Seals, Figurines and Rock-Carvings," in Aspects of Art and Iconography, ed. Mellink, Porada, and Özgüç, 433-99; cally for representations of the royal body reveals that there were standard elements repeated across different genres.

In their anthropomorphic representations, Hittite kings are depicted wearing two different types of attire: ceremonial and martial. When in their ceremonial regalia, kings wear long dresses, shoes with curled toes, rounded caps, and hold curved wands (lituus), ${ }^{39}$ all attributes of the Sun God, one of the chief gods of the state, whose title (literally "My Sun") the Hittite language utilized for the word majesty, thus reinforcing the bond between the Sun God and the king. ${ }^{40}$ When depicted in their so-called "martial" outfits, a second major role of the Hittite king was being emphasized: the king as the general of the army, and leading the annual military campaigns under the protection of the gods. The role of the king as warrior is alluded to in some rock reliefs and seals, where the kings are dressed in conical, pointed hats and short skirts, while they carry lances or bows on their shoulders, attributes borrowed from the depictions of martial gods and the Storm God. ${ }^{41}$ Except for the weapon(s) that the king carries, however, the socalled "martial image" contains no visual clues about military engagement. In Mesopotamian iconography, there was a strong tradition of depicting kings fighting the enemy, from the Victory Stele of the Akkadian king Naram-Sin shown killing the Lullubi, ${ }^{42}$ to countless reliefs exhibiting Neo-Assyrian kings attacking and subduing enemies. ${ }^{43}$ Similarly, Egyptian pharaohs

Özyar, "A Prospectus of Hittite Art"; Schachner, "Gedanken zur Datierung"; A. Schachner, "On the Development of Hittite Art and Its Social Functions," in Hittites: An Anatolian Empire, ed. M. Doğan-Alparslan and M. Alparslan (İstanbul, 2013), 534-63.

${ }^{39}$ The Anatolian depiction of the curved wand on the side of the king is so far unique in late second millennium $\mathrm{BC}$ iconography of the eastern Mediterranean, and it was used to distinguish the king from similarly-dressed attendants: Lumsden, Symbols of Power, $105,119$.

${ }^{40}$ H. G. Güterbock, "Sungod or King?," in Aspects of Art and Iconography, ed. Mellink, Porada, and Özgüç, 225-226.

${ }^{41}$ D. Bonatz, "The Divine Image of the King: Religious Representation of Political Power in the Hittite Empire," in Representations of Political Power: Case Histories from Times of Change and Dissolving Order in the Ancient Near East, ed. M. Heinz and M. Feldman (Winona Lake, IN, 2007), 120-21.

${ }^{42}$ Cf. I. J. Winter, "Sex, Rhetoric and the Public Monument: The Alluring Body of Naram-Sîn of Agade," in Sexuality in Ancient Art: Near East, Egypt, Greece and Italy, ed. N. B. Kampen and B. Bergmann (Cambridge, 1996), 11-26.

${ }^{43}$ For example, reliefs from Ashurbanipal's palace in Nineveh depict a series of events from the battle of Til-Tuba, starting with 
Table 1-Anthropomorphic representations of the Hittite kings discussed in the article

\begin{tabular}{|c|c|c|c|c|c|c|}
\hline & Artifact / Monument & Provenance & Medium & King Depicted & Attire & Mode of Representation \\
\hline 1 & Macridy Block 13 & Alaca Höyük & Orthostat & Anonymous & Ceremonial & Divine encounter \\
\hline 2 & Silver fist vessel (MFA 2004.2230) & Unprovenanced & Metal vessel & Tudhaliya I/II or III & Ceremonial & Divine encounter \\
\hline 3 & BOĞAZKÖY 19 & Hattuša & Orthostat & Tudhaliya & Martial & God-King \\
\hline 4 & SÜDBURG & Hattuša & Orthostat & Šuppiluliuma & Martial & God-King \\
\hline 5 & SIRKELI & Sirkeli & Rock relief & Muwatalli II & Ceremonial & God-King \\
\hline 6 & Cat.No. 39* & Nişantepe & Seal & Muwatalli II & Ceremonial & Embraced by god \\
\hline 7 & Cat.No. 40 & Nişantepe & Seal & Muwatalli II & Ceremonial & Embraced by god \\
\hline 8 & Cat.No. 41 & Nişantepe & Seal & Muwatalli II & Ceremonial & Embraced by god \\
\hline 9 & Cat.No. 42 & Nişantepe & Seal & Muwatalli II & Ceremonial & Embraced by god \\
\hline 10 & Cat.No. 43 & Nişantepe & Seal & Muwatalli II & Ceremonial & Embraced by god \\
\hline 11 & Cat.No. 44 & Nişantepe & Seal & Muwatalli II & Ceremonial & Embraced by god \\
\hline 12 & Cat.No. 53 & Nişantepe & Seal & Mursili III & Ceremonial & Embraced by god \\
\hline 13 & Cat.No. 57 & Nişantepe & Seal & Mursili III & Martial & God-King \\
\hline 14 & FRAKTIN & Fraktin & Rock relief & Hattusili III & Martial & Divine encounter \\
\hline 15 & YAZILIKAYA 64 & Yazılıkaya & Rock relief & Tudhaliya IV & Ceremonial & God-King \\
\hline 16 & YAZILIKAYA 81 & Yazılıkaya & Rock relief & Tudhaliya IV & Ceremonial & Embraced by god \\
\hline 17 & YALBURT & Yalburt & Orthostat & Tudhaliya IV & Martial & Embraced by god \\
\hline 18 & RS17.159 'Ugarit Seal' & Ugarit & Seal & Tudhaliya IV & Martial & Embraced by god \\
\hline 19 & Cat.No. 101 & Nişantepe & Seal & Tudhaliya IV & Martial & Embraced by god \\
\hline
\end{tabular}

* Catalog numbers refer to Herbordt, Bawanypeck, and Hawkins, Die Siegel der Grosskönige und Grossköniginnen.

commissioned many reliefs and sculptures rendering them as warriors. ${ }^{44}$ Contrary to these other eastern Mediterranean traditions, the Hittite king is almost never depicted engaged in confronting enemies. ${ }^{45} \mathrm{In}$ the so-called martial images, the king either stands alone or in the company of the gods, never engaged in active battle.

Hittite texts, however, are full of records of annual campaigns, battles, and suppressed rebellions. The Ten-Year Annals of Muršili II, for instance, recounts his campaigns outside of the Maraššantiya River, and tells of the immense number of inhabitants and cattle he carried off to Hattuša while burning down enemy

the military campaign of the king, proceeding with the escape of the Elamite king Teumman, his capture and beheading, and ending with the marching of his head to Nineveh for the final display in the victory banquet of Ashurbanipal. The relief series are accompanied by an inscription detailing the events and promoting the acts of Ashurbanipal. Z. Bahrani, Rituals of War (New York, 2008), 23-42.

${ }^{44}$ Cf. L. Bestock, Violence and Power in Ancient Egypt: Image and Ideology before the New Kingdom (New York, 2018) for a recent and thorough treatment of royal imagery and violence in PreDynastic, Old Kingdom, and Middle Kingdom Egypt.

${ }^{45}$ The only possible exceptions are: an Old Hittite relief found in Büyükkale seemingly depicting a fighting scene including a chariot, though the royal presence is not certain; and another fragment which might depict a fighting scene judging from the dynamic rendering of figures. Schachner, "Gedanken zur Datierung": 133-34. cities. ${ }^{46}$ This stark contrast between the textual and figural treatments of warfare calls the "martial" nature of these depictions into question. For this reason, I choose not to use one of the conventional classifications in the literature about the anthropomorphic representations of the Hittite king, i.e., the distinction drawn between his "ceremonial" and "martial" images. ${ }^{47}$ Instead, I identify scenes based on three different kinds of actions: the king facing a deity (and either saluting or libating to him, i.e., the "divine encounter"), the king embraced by a protective deity (i.e., the "Umarmungszene"), and the king portrayed alone, which I argue below to be when he is a god himself (i.e., the "God-King").

A thorough exploration of the corpus of anthropomorphic representations securely identified as Hittite Great Kings reveals an uneven distribution between these three different modes (see Table 1). Most of the corpus is made up of the Umarmungszene, seen

${ }^{46}$ A. Goetze, Die Annalen des Muršilišs, MVAeG 38 (Leipzig 1933).

47 The two different attires the Hittite king wears have been the basis of classification for his anthropomorphic representations in many scholarly works, such as T. van den Hout, "Tuthalija IV und die Ikonographie Hethitischer Großkönige des 13. Jhs.," BiOr 52 (1995): 545-83; Bonatz, "The Divine Image of the King"; G. M. Beckman, "The Horns of a Dilemma, or On the Divine Nature of the Hittite King," in Organization, Representation and Symbols of Power in the Ancient Near East, ed. G. Wilhelm (Winona Lake, 2012), 605-10. 
predominantly on seals. Second most common is the God-King, executed on orthostats, rock reliefs, and seals. The divine encounter makes up a small percentage of the corpus and is not represented on seals. In terms of attire, the kings are dominantly represented in their ceremonial regalia. Chronologically, these representations date to the reigns of at least six kings: Tudhaliya (I/II and/or III), ${ }^{48}$ Suppiluliuma I, ${ }^{49} \mathrm{Mu}-$ watalli II, Muršili III, Hattušili III, and Tudhaliya IV. Overall, the representations of Muwatalli II constitute a considerable portion of the corpus, executed on two new media: rock reliefs and seals.

An important caveat in this corpus is royal statuary. Texts mention that statues of Hittite kings were put up as votive offerings to the gods, as exemplified by the statue of himself that Hattušili I dedicated (in gold, to the goddess Arinna) after his conquest of the city of Hahha; ${ }^{50}$ or Puduhepa's prayer to the goddess Lelwani, in which she promised her a life-size statue of Hattušili III as a votive offering for the health of the king to improve. ${ }^{51}$ Textual evidence also suggests that statues of deceased Hittite kings were displayed in temples as recipients of offerings in ancestor cult. ${ }^{52}$ None of these statues are preserved, however, with the possible exception of a statue base found at Yazllıkaya, and two feet found at the nearby village of Yekbaz fitting the base seamlessly. It was suggested that the base and the fragments belonged to a statue of Tudhaliya IV, whose cartouche is carved on the adjacent rock face, which might have been part of his final resting place. ${ }^{53}$ While I am not able to include royal statuary as a genre in this paper in the absence of preserved examples, it is still possible to conduct observations on the preserved references. Through an in-depth analysis of textual and archaeological evidence pertaining to Late Bronze Age sculpture, S. Aro was able to suggest that early examples of Hittite royal

\footnotetext{
${ }^{48}$ See nn. 60 and 83 , below.

${ }^{49}$ See n. 83, below.

${ }^{50}$ A. Gilan, "Hittite Religious Rituals and the Ideology of Kingship," Religion Compass 5/7 (2011): 280.

${ }^{51}$ CTH 384 "Puduhepa's Prayer to the Sun-goddess of Arinna and her Circle for the Well-being of Hattusili” $\$ 9^{\prime}\left(\right.$ iii $36^{\prime}-42^{\prime}$ ): I. Singer, Hittite Prayers (Atlanta, 2002), 104.

${ }^{52}$ van den Hout, "Death as a Privilege," 45.

${ }^{53}$ P. Neve, "Einige Bemerkungen zur Kammer B in Yazılıkaya," in Anatolia and the Ancient Near East: Studies in Honor of Tahsin Özgüç, ed. K. Emre et al. (Ankara, 1989), 350-51; Bonatz, "The Divine Image of the King," 116-17; van den Hout, "Death as a Privilege," 52.
}

statuary were always located in temples or shrines. ${ }^{54}$ These statues would mark encounters between the royal and the divine. KBo 12.38, however, could be interpreted to suggest that a statue of Tudhaliya IV and another one of Šuppiluliuma II himself were erected during the reign of Šuppiluliuma II, likely in Yazılıkaya and Nişantaş, respectively. ${ }^{55}$ These two statues would be objects of ancestor cult, with the statue of the king marking an instance in which the king was divine himself. Even without preserved examples, we can tentatively suggest that Hittite royal statuary fit within the overall framework of royal anthropomorphic imagery advocated in this paper, and depicted instances of the divine encounter, or the God-King. I now turn to the preserved examples of the corpus for a thorough exploration of the different scenes and their implications.

\section{The Divine Encounter}

The Hittite kings partook in and oversaw several ceremonies and festivals, making Hittite kingship partly a religious task. As texts demonstrate, the Hittite king was the chief priest of the state deities, first of the Storm God and then of the Sun Goddess of Arinna, and he stood at the point of interaction between the spheres of gods and humans. The land of Hatti belonged to the Storm God, and the king was its steward. ${ }^{56}$ Hittite texts present many instances highlighting the religious character of Hittite kingship. One significant example is "Hattušili's Apology," in which Hattušili III celebrates Ištar, then describes the circumstances under which the goddess saved his life, and how he went on to become her priest. ${ }^{57}$ The kings encountering deities thus belong to this realm of enacting kingship, where the legitimacy of rule was directly channeled from the divine sphere.

Three examples depict kings encountering the divine. On the city wall of Alaca Höyük, the king

\footnotetext{
${ }^{54}$ S. Aro, "Carchemish before and after 1200 BC," in Luwian Identities: Culture, Language and Religion between Anatolia and the Aegean, ed. by A. Mouton, I. Rutherford, and I. Yakubovich (Leiden, 2013), 242.

${ }^{55}$ Ibid, 240-42.

${ }^{56}$ G. M. Beckman, "Royal Ideology and State Administration in Hittite Anatolia," in Civilizations of the Ancient Near East, ed. J. M. Sasson et al. (New York, 1995), 530.

${ }^{57}$ Cf. lines I1-I74 as transliterated and translated in H. Otten, Die Apologie Hattusilis III. Das Bild der Überlieferung, STBoT 24 (Wiesbaden, 1981), 4-9.
} 

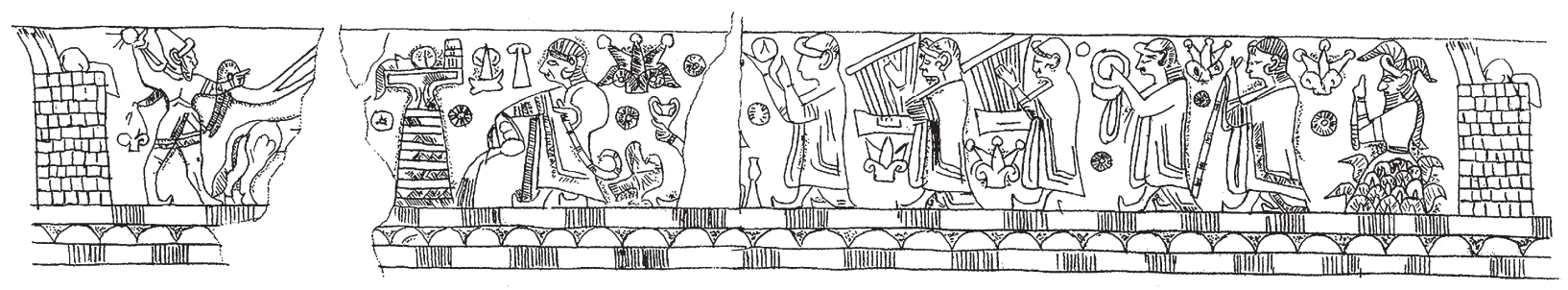

Figure 3-The silver vessel in the form of a fist (MFA 2004.2230) (drawn by the author, after Güterbock and Kendall, "A Hittite Silver Vessel in the Form of a Fist," Figure 3.7).

is shown saluting the statue of a bull representing the Storm God (Macridy Block 13). ${ }^{58}$ In Fraktin, Hattušili III is shown libating to the Storm God in front of an altar. ${ }^{59}$ On the silver vessel in the form of a fist (MFA 2004.2230), Tudhaliya, ${ }^{60}$ followed by a line of attendants, is depicted pouring libations in front of an altar before a god holding the reins of two bulls (Figure 3). ${ }^{61}$ The posture of the king and the standing god in this representation prioritize only the king in the encounter with the divine, while the king has no physical or visual contact with the attendants. The honor of being visually depicted in direct engagement with the gods belonged to the Hittite king, ${ }^{62}$ but this

${ }^{58} \mathrm{P}$. Taracha has argued for a later date for the city wall, very likely during the reign of Tudhaliya IV in "The Iconographic Program of the Sculptures of Alacahöyük," JANER 11/2 (2011): 142-47, and "The Sculptures of Alacahöyük: A Key to Religious Symbolism in Hittite Representational Art," NEA 75/2 (2012): 108-15. Others have advocated an earlier date, e.g., A. Ünal, "The Textual Illustration of the 'Jester Scene' on the Sculptures of Alaca Höyük," Anatolian Studies 44 (1994): 210-18; and Seeher, "Der Landschaft Sein Siegel Aufdrücken": 125. The parallels between the iconography of the Alaca Höyük scene and the silver vessel in the form of a fist (discussed immediately below) and the Kayalipınar relief advocate for an earlier date: Güterbock and Kendall, "A Hittite Silver Vessel in the Form of a Fist," 56-57; Schachner, "Gedanken zur Datierung": 139. In the absence of scholarly consensus, I take this relief as an anonymous representation, but maintain that it should be dated as pre-13th century BC.

${ }^{59}$ Kohlmeyer, "Felsbilder der Hethitischen Großreichzeit": 69-70, Tafeln 24, 136.

${ }^{60}$ The king in question here should be earlier than Tudhaliya IV based on iconography and the rendering of the royal name, which suggests a dating to either Tudhaliya I/II or III. Güterbock and Kendall, "A Hittite Silver Vessel in the Form of a Fist," 56-57.

${ }^{61}$ Güterbock and Kendall, "A Hittite Silver Vessel in the Form of a Fist," 45-50.

${ }^{62}$ While my argument here specifically concerns the Hittite king because of the focus of this paper, the same privilege was valid for Hittite queens, as evidenced by the relief of Puduhepa libating to the goddess Hepat in Fraktin. Bonatz, "The Divine Image of the King," 113; Kohlmeyer, "Felsbilder der hethitischen Großreichzeit": 69-70, Tafeln 24, 136. engagement had its limitations. In the examples of divine encounter, there is an altar between the mortal and the immortal, marking the different territories of human and god.

Thus, the libation scenes demonstrate a divine interaction, in which the king is directly facing a god, while still standing in a separate space. In the mortal plane occupied by the king and others, the king was the only one depicted as directly encountering the deity being honored. Performing in honor of and in front of the gods clearly established a bond between the divine and the royal, making these images politically-embedded statements that sought to legitimize the power of the ruling dynasty. This form of representation had roots in the 16th century BC relief vases depicting cult performances, and seems to have fallen out of favor during the 13th century BC except for Fraktin. It is possible to see this decline as related to the rise of the embrace scenes starting with the reign of Muwatalli II. If this indeed was the case, a revised notion of kingship was being conveyed in the 13th century $\mathrm{BC}$ : that the king was not only able to communicate with the gods, but was also directly under their protection.

\section{The King Embraced by a Deity}

The second mode of representation of the Hittite king is the type of scene known as Umarmungsszene, where the king is in the protective embrace of a deity. ${ }^{63}$ As opposed to the encounter scenes in which the king and the god confront each other, the king is almost

${ }^{63} \mathrm{H}$. Klengel, "An der Hand der Gottheit: Bemerkungen Zur 'Umarmungsszene' in der Hethitischen Tradition," in Silva Anatolica. Anatolian Studies Presented to Maciej Popko on the Occasion of His 65th Birthday, ed. P. Taracha (Warsaw, 2002), 205-10; S. Herbordt, "The Hittite Royal Cylinder Seal of Tuthaliya IV with Umarmungsszene," in The Iconography of Cylinder Seals, Warburg Institute Colloquia 9, ed. P. Taylor (London, 2006), 83; Seeher, "Der Landschaft Sein Siegel Aufdrücken": 127. 
absorbed by the god in the embrace scenes, and both figures look like parts of one indivisible unit. This is clearly visible in the legs and feet, as they seem to overlap, and most scenes demonstrate only three feet instead of four.

As a motif, the embrace scene makes up most of the anthropomorphic representations of the Hittite kings, and is mostly found on stamp seals. Representations of the royal body may exist in cylinder seal impressions deriving mainly from north Syrian sites, but the figures always bear attributes that belong to the divine realm, such that it is mostly impossible to distinguish between the gods and the kings. ${ }^{64}$ Furthermore, even if these individuals depict "Hittite" kings, it remains possible that they would depict the kings of Carchemish, who had oversight of northern Syria, while the Hittite Great King at Hattuša would only interfere when the administration of Carchemish proved unsuccessful..$^{65}$ This confusion of the king and the god may have been a strategy in itself, invoking both divine and royal legitimacy at the same time. ${ }^{66}$

The earliest embrace scene representation of the Hittite King on seals dates to the reign of $\mathrm{Mu}-$ watalli II. ${ }^{67}$ Multiple impressions of a single seal and its variations depict the king in the embrace of the Storm God (Figure 4) ${ }^{68}$ Behind the king, hieroglyphic signs read "Great King Muwatalli." The deity holds his own label, "Storm God" with his left hand. ${ }^{69}$ Muwatalli II's seals with the Storm God also make up the majority of this iconography on Hittite seals. Other examples of this genre are Muršili III's seal depicting him in

${ }^{64}$ Beyer, Emar IV: Les Sceaux, 351-53.

${ }^{65}$ G. M. Beckman, "Ugarit and Inner Syria During the Late Bronze Age," in Le Royaume D'ougarit De La Crète à L'euphrate: Nouveaux Axes De Recherche, ed. J.-M. Michaud (Sherbrooke, 2007), 163-64. Also see Bonatz, "The Divine Image of the King," 128-30 for a survey of the depictions of Ini-Tešub, king of Carchemish, with divine attributes.

${ }^{66}$ This deliberate ambiguity between the king and the god was also suggested for rock monuments: Ö. Harmanşah, "Figures Carved on the Living Rock: Hittite Rock Monuments," in Hittites: An Anatolian Empire, ed. M. Doğan-Alparslan and M. Alparslan (İstanbul, 2013), 569 .

${ }^{67}$ Herbordt, "Hittite Royal Cylinder Seal," 85.

${ }^{68}$ Güterbock, Siegel aus Boğasköy I, 19-25, Cat. Nos. 38-40; Beran, Die Hethitische Glyptik von Boğazköy I. Teil, 79, Cat. Nos. 250-52; Herbordt, "Hittite Royal Cylinder Seal," 85, Figures 134, 208; Herbordt, Bawanypeck, and Hawkins, Die Siegel der Grosskönige und Grossköniginnen, 125-35 Cat. Nos. 39-45, Tafeln 9-15.

${ }^{69}$ S. Alp, Hitit Cağında Anadolu: Çiviyazıl ve Hiyeroglif Yazılı Kaynaklar (Ankara, 2000), 172.

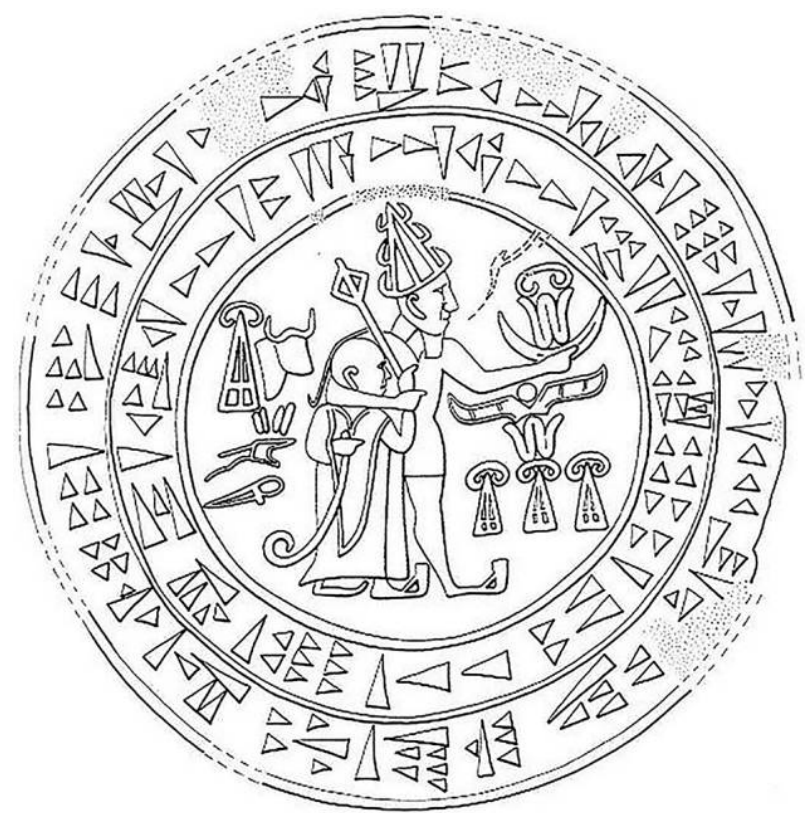

Figure 4-Composite drawing of a stamp seal of Muwatalli II showing him in the embrace of the Storm God (Herbordt, Bawanypeck, and Hawkins, Die Siegel der Grosskönige und Grossköniginnen, Cat. Rek. 39.1-11, Tafel 9. Copyright Archive of the BoğazköyExpedition, DAI Berlin). Image courtesy of Suzanne Herbordt.

the embrace of the Storm $\mathrm{God}^{70}$ and two seals of Tudhaliya IV with the same deity - one stamp seal, ${ }^{71}$ and one cylinder seal. ${ }^{72}$ In Yazilikaya 81, Tudhaliya IV is depicted in the embrace of his protective deity Šarruma, both identified with hieroglyphic labels (Figure 5). ${ }^{73}$ In a fragmentary relief found in the Yalburt Sacred Pool Complex, Tudhaliya IV is depicted in the embrace of the mountain god, distinguishable by his skirt representing a mountain. ${ }^{74}$

The embrace scenes reinforce the religious connotations of the office of Hittite kingship. By suggesting that the king and the god were parts of one indivisible unit, support was bestowed upon him by his protective deity. The dominance of the embrace scenes on seals, which would travel to the vassal states, neighboring kingdoms, and throughout the empire

${ }^{70}$ P. Neve, "Die Ausgrabungen in Boğazköy-Hattuša 1990," Archäologischer Anzeiger 1991/3: 329, Figure 29b.

${ }^{71}$ C. F. A. Schaeffer, Ugaritica III (Paris, 1956), 19-21, figs. 24-26.

${ }^{72}$ Herbordt, Bawanypeck, and Hawkins, Die Siegel der Grosskönige und Grossköniginnen, 192-93, Cat. No. 101, Tafel 40.

${ }^{73}$ Ehringhaus, Götter, Herrscher, Inschriften, 29.

${ }^{74}$ C. Karasu, M. Poetto, and S. Ö. Savaş, "New Fragments Pertaining to the Hieroglyphic Luwian Inscription of Yalburt," Archivum Anatolicum 4 (2000): 100. 


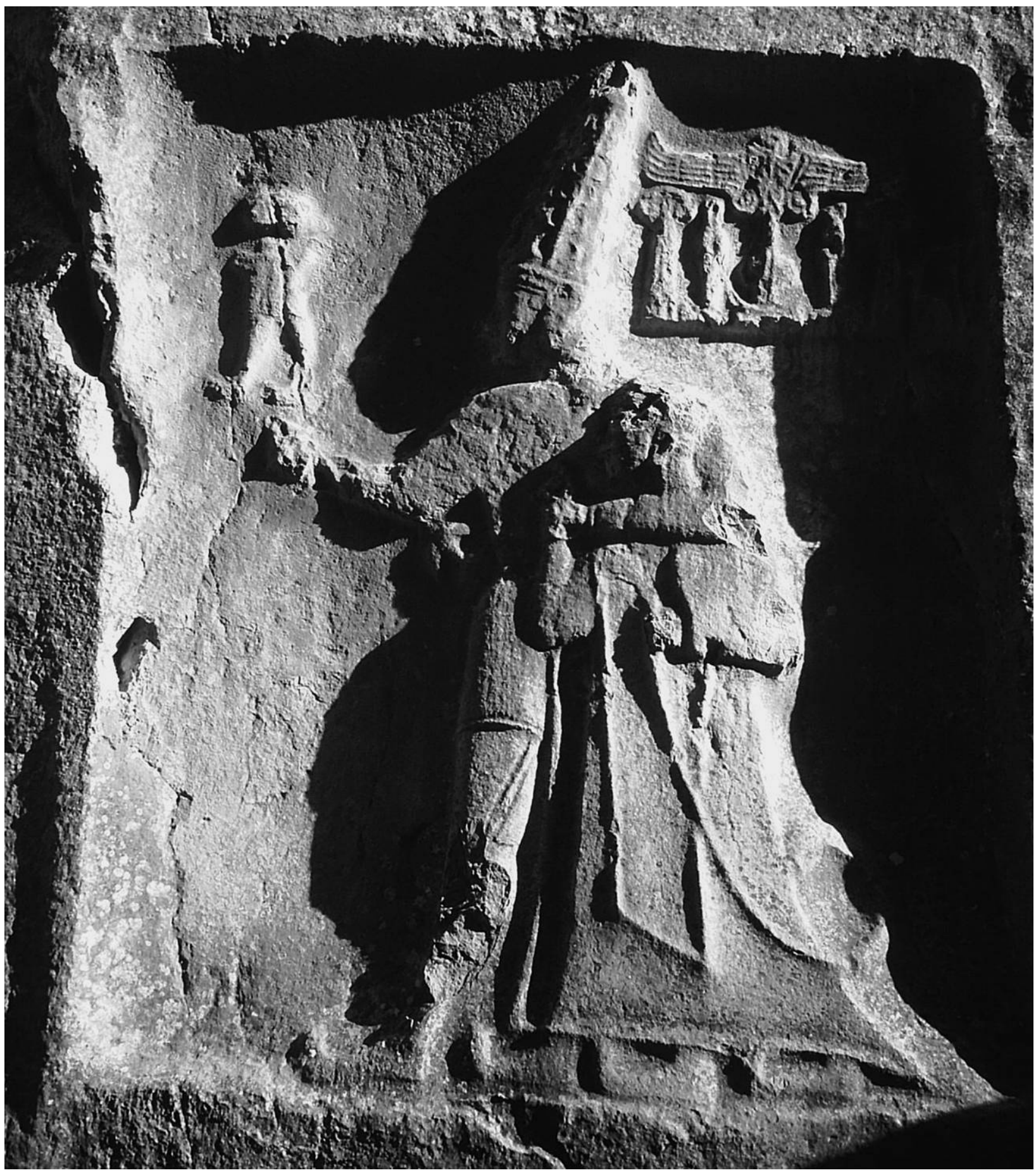

Figure 5-YAZILIKAYA 81, depicting Tudhaliya IV in the embrace of Šarruma (photo by author).

on administrative texts, letters, and treaties, renders the dominance of this iconography as a specific message intended for the administrative elites throughout the empire and beyond. Hittite texts offer plenty of examples for the rebellions of the vassal kingdoms and conflicts with neighboring states during the 13 th century BC, ${ }^{75}$ which might have been a motivation for a renewed interest in demonstrating an even closer relationship between the Hittite kings and gods. The rise

${ }^{75}$ R. H. Beal, "Hittite Anatolia: A Political History," in Oxford Handbook of Ancient Anatolia, ed. Steadman and McMahon, 591-96. 
of the embrace scenes specifically in the 13th century thus finds a correlation in the fragile political climate of the late empire period.

\section{The God-King}

In the representations I term the "God-King," the king is depicted as divine himself, marked either by iconographic details in his martial attire, such as wearing a horned cap, or through a post-mortem context while depicted in his ceremonial regalia. Although Hittite kings frequently interacted with the divine through rituals and festivals, the Hittite kings and queens were not perceived to be divine themselves, but became gods upon death. ${ }^{76}$ The texts of the royal funerary ritual describe in detail the actions needed to be undertaken in a particular order to facilitate the transition of the Hittite king or queen from the mortal realm to the divine. On the first day of the fourteenday ritual, the body was cremated. ${ }^{77}$ The deceased royal was then channeled into an effigy for the rest of the funeral. This effigy not only acted as the deceased (through a substitute ritual), but also lacked his/her fragilities, such as the decaying of the corpse. ${ }^{78}$ After the body was cremated and channeled into the effigy, specific items that were deemed to be important for the afterlife were sent to the Netherworld by means of consumption with fire. ${ }^{79}$

A contextual reading of two anthropomorphic representations reveal them to be images of the God-King. At Sirkeli, Muwatalli II is depicted without any seem-

${ }^{76}$ G. Beckman, "The Religion of the Hittites" Biblical Archaeologist 52/2-3 (1989): 101; H. Otten, Hethitische Totenrituale (Berlin, 1958).

77 Ibid.; L. Christmann-Franck, "Le Rituel des Funérailles Royales Hittites," Revue Hittite et Asianique 71 (1971): 61-84; van den Hout, "Death as a Privilege"; I. Singer, “In Hattuša the Royal House Declined': Royal Mortuary Cult in 13th Century Hatti," in Central-North Anatolia in the Hittite Period: New Perspectives in Light of Recent Research. Acts of the International Conference Held at the University of Florence (7-9 February 2007), Studia Asiana 5, ed. F. P. Daddi, G. Torri, and C. Corti (Roma, 2009), 169-99.

${ }^{78}$ van den Hout, "Death as a Privilege," 63; T. van den Hout, "An Image of the Dead? Some Remarks on the Second Day of the Hittite Funerary Ritual," in Atti Del Ii Congresso Internazionale Di Hittitologia, ed. O. Carruba, M. Giorgieri, and C. Mora (Pavia, 1995), 199.

${ }^{79}$ T. van den Hout, "Tombs and Memorials: The (Divine) Stone-House and Hegur Reconsidered," in Recent Developments in Hittite Archaeology and History: Papers in Memory of Hans G. Güterbock, ed. K. A. Yener and H. A. Hoffner (Winona Lake, IN, 2001), 73 . ingly divine attributes, but in a post-mortem setting (Figure 6). The relief is connected with a monumental building built into a rock outcrop with cup-marks; $;{ }^{80}$ as well as a second relief of possibly either Muršili III (Muwatalli II's son) or Kurunta (his brother) that had been erased in antiquity. ${ }^{81}$ It is plausible to read SiRKeLI as a site of sustained ancestor cult for Muwatalli II, whose memory overtook the significance of the figure in the erased relief..$^{82}$ Another example (BoĞAZKöy 19) from Temple 5 in Hattuša depicts a figure in martial outfit, holding a lance and identified with the hieroglyphic signs reading "Great King Tudhaliya" (Figure 7). ${ }^{83}$

${ }^{80}$ A. Ahrens, E. Kozal, and M. Novák, "Sirkeli Höyük in Smooth Cilicia. A General Overview from the 4th to the lst Millennium BC," in Proceedings of the 6th International Congress on the Archaeology of the Ancient Near East May 5th-10th 2008, "Sapienza" - Università Di Roma. Volume 2: Excavations, Surveys and Restorations: Reports on Recent Field Archaeology in the Near East, ed. P. Matthiae et al. (Wiesbaden, 2010), 58-59; E. Kozal and M. Novák, "Facing Muwatalli: Some Thoughts on the Visibility and Function of the Rock Reliefs at Sirkeli Höyük, Cilicia," in Questions, Approaches, and Dialogues in Eastern Mediterranean Archaeology: Studies in Honor of Marie-Henriette and Charles Gates, ed. E. Kozal et al. (Münster, 2017), 379-82.

${ }^{81} \mathrm{H}$. Ehringhaus, "Hethitisches Felsrelief Der Grossreichszeit Entdeckt," Antike Welt 26/1 (1995): 66; H. Ehringhaus, "Ein Neues Hethitisches Felsrelief am Sirkeli Höyük in der Çukurova," Antike Welt 26/2 (1995): 118-19; B. Hrouda, "Damnatio Memoriae?' Neue Beobachtungenam Relief Nr. 2 Bei Sirkeli/Türkei," Antike Welt 28/6 (1997): 471-74; Ehringhaus, Götter, Herrscher, Inschriften; M. Novák et al., "2006-2007 Yıllarında Sirkeli Höyük'te (Adana-Ceyhan) Yapılan Türk-Alman Kazıları,” Kazı Sonuçları Toplantısı 30/3 (2009): 297. Recently, E. Kozal and M. Novák advocated the identification of the erased relief with Muršili III: E. Kozal and M. Novák, "Facing Muwatalli: Some Thoughts on the Visibility and Function of the Rock Reliefs at Sirkeli Höyük, Cilicia," 375-79.

${ }^{82}$ Balza and Mora identify SirkeLi as a possible royal funerary monument, defined as $\mathrm{NA}_{4}$ bekur SAG.uš, in Hittite texts. Balza and Mora, “'And I Built This Everlasting Peak for Him'”: 220 n. 20.

${ }^{83}$ Previously, P. Neve has interpreted Temple 5 as an ancestor cult temple built by Tudhaliya IV where different rooms were dedicated to the veneration rituals of different kings (P. Neve, "BoğazköyHattuša. Ergebnisse der Ausgrabungen in der Oberstadt," Anatolica 14 [1987]: 63-64. The recently revised chronology of the building activities in Hattuša's Upper Town as argued by J. Seeher and A. Schachner call this identification into question, and suggest that the Upper Town expansion should be dated earlier, possibly to the 16th century BC: e.g., J. Seeher, "Chronology in Hattuša: New Approaches to an Old Problem," Structuring and Dating in Hittite Archaeology, ed. Mielke, Schoop and Seeher (Istanbul, 2006), 197-213; J. Seeher, "Hattusa - Tuthalija Stadt? Argumente für eine Revision der Chronologie der hethitischen Hauptstadt," The Life and Times of Hattusili III. And Tuthaliya IV. Proceedings of a Symposium Held in Honour of J. de Roos, 12-13 December 2003, Leiden (Leiden, 2006), 131-46; A. Schachner, "Das 16. Jahrhundert v. 


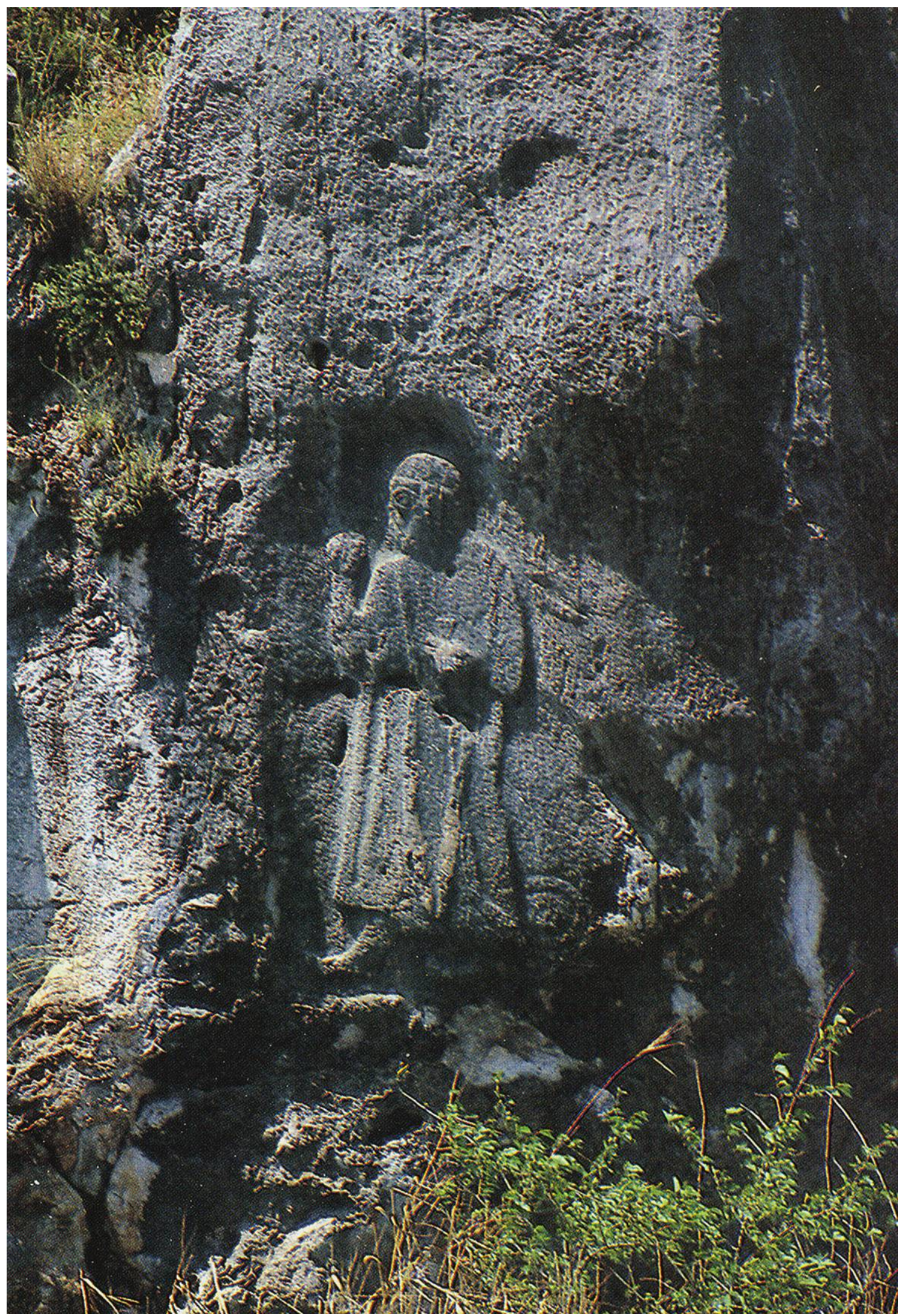

Figure 6-SIRKeli, depicting Muwatalli II (Photo by Horst Ehringhaus. Copyright Sirkeli Höyük Project, Bern University). Photograph courtesy of Mirko Novak. 
Coupled with the context of Temple 5 , this image can be read as an ancestral and deified Tudhaliya venerated in this room. ${ }^{84}$ The representations from Sirkeli and Temple 5, thus, are images of ancestors who were deceased and deified Hittite kings.

In other iterations of the God-King representation, the kings are depicted with unmistakably divine attributes, specifically with conical hats adorned with horns that have been used as symbols of divinity in the Near East since the third millennium BC. The SÜDBURG monument in Hattuša depicts a Šuppiluliuma in the martial outfit wearing a horned hat. Originally dated to the reign of Šuppiluliuma II, there is now an intense academic debate surrounding the patronage of this monument. ${ }^{85}$ In a seal of Muršili III, the king is depicted standing beside the Storm God of Aleppo, wearing the martial outfit, with one foot stretched forward. ${ }^{86}$ As seals would be in circulation during the

Chr. - eine Zeitenwende im hethitischen Zentralanatolien," Istanbuler Mitteilungen 59 (2009): 9-34; A. Schachner, "M.Ö. 16. Yüzyıl: Hitit Anadolusu'nda bir Dönüm Noktası," VII. Uluslararası Hititoloji Kongresi Bildirileri Çorum 25-31 Ağustos 2008, ed. A. Süel (Ankara, 2010), 661-88. This argument covers the so-called Temple District as well as the structures around NișANTAŞ. It is thus possible that Temple 5 was built by Tudhaliya I/II or III, or another early king who wanted to include an ancestral Tudhaliya in cult veneration. A certain identification is not possible at this time.

${ }^{84}$ Neve, "Boğazköy-Hattuša. Ergebnisse der Ausgrabungen in der Oberstadt," 64 and Gonnet's additional note in the same article, p. 70; Bonatz, "The Divine Image of the King," 119; I. Singer, “'In Hattuša the Royal House Declined', 180; Lumsden, Symbols of Power: Hittite Royal Iconography in Seals, 101-102.

${ }^{85}$ The archaeological re-dating of SÜDBURG is part of a larger conversation about the chronology of Hattuša, cf. n. 83. There is also a philological debate surrounding the monument: the original publication dated the monument to the reign of Šppiluliuma II, while also acknowledging its "archaizing" nature: Hawkins, Hieroglyphic Inscription of the Sacred Pool Complex, 21. Many publications since then adhered to this dating: e.g., G. M. Beckman, "Intrinsic and Constructed Sacred Space in Hittite Anatolia," Heaven on Earth: Temples, Rituals, and Cosmic Symbolism in the Ancient World, ed. D. Ragavan, Oriental Institute Seminars 9 (Chicago, 2013), 158. Other scholars, however, argued for dating the inscription to the reign of Šppiluliuma I based on the peculiar aspects of the script: e.g., R. Oreshko, Studies in Hieroglyphic Luwian: Towards a Philological and Historical Interpretation of the SÜDBURG Inscription (Ph.D. dissertation, Free University of Berlin, 2016). Even if one accepts a later date, however, it remains possible for the relief to represent Šuppiluliuma I as a deified ancestor, as originally suggested by Hawkins, Hieroglyphic Inscription of the Sacred Pool Complex, 19-20; I. Singer, “ 'In Hattuša the Royal House Declined'” 180.

${ }^{86}$ Herbordt, Bawanypeck, and Hawkins, Die Siegel der Grosskönige und Grossköniginnen, Figs. 17 c-d, 59, Cat. Nos. 57, 157-58, Tafel 19. lifetime of the king, this particular seal of Muršili III calls into question his earthly nature, and may mean that Muršili III started a tradition of incorporating aspects of divine iconography into royal representation while he still reigned as a living king. ${ }^{87}$

A more definitive exception to the post-mortem deification of the Hittite king can be found in the reign of Tudhaliya IV. In the representation of Tudhaliya IV in Yazilikaya 64, the king is shown standing on two mountains, a symbol of divinity, while his name in hieroglyphic Luwian stretches below a drawing of the winged sun disk (Figure 8). ${ }^{88}$ The mountains in these reliefs mark divine status and clearly situate the body of the king in the divine realm. Textual evidence might indeed suggest that Tudhaliya IV was deified during his lifetime. Emirgazi altars, erected during the reign of Tudhaliya IV, mention votive offerings to be made to him, making it possible to suggest that the king was already deified before his death. ${ }^{89}$ The divine status of Tudhaliya IV as symbolized with the horned caps is visible even in the Umarmungszene, such as on his cylinder seal, where both the god and the king are wearing matching hats and outfits. ${ }^{90}$

A particular motivation for Tudhaliya IV's deification during his lifetime might be his political troubles. On the one hand, his cousin Kurunta, king of Tarhuntašša and son of Muwatalli II, might have claimed the Hittite throne. Kurunta was initially loyal to Tudhaliya IV, whom the king favored with measures of power second only to himself. ${ }^{91}$ Despite this seeming stability, a rock relief at HATIP identifying Kurunta as "Great King, Hero, Son of Muwatalli, Great King, Hero," $" 2$ and impressions of an aedicula seal using

\footnotetext{
${ }^{87}$ van den Hout, "Tuthalija IV und die Ikonographie Hethitischer Großkönige des 13. Jhs.”: 559.

${ }^{88}$ Ehringhaus, Götter, Herrscher, Inschriften, 25-26, Fig. 38.

${ }^{89} \mathrm{E}$. Masson, "Les inscriptions louvites hiéroglyphiques d'Emirgazi," Journal des savants 12 (1979): 27; Hawkins, Hieroglyphic Inscription of the Sacred Pool Complex, 88-89, Emirgazi altars $\mathrm{A}+\mathrm{B}+\mathrm{C}+\mathrm{D} \$ 33-37$; van den Hout, "Tuthalija IV und die Ikonographie Hethitischer Großkönige des 13. Jhs.”: 561-64.

${ }^{90}$ Herbordt, Bawanypeck, and Hawkins, Die Siegel der Grosskönige und Grossköniginnen, Cat. Nos. 101, 192-93, Tafel 40.

${ }^{91}$ Bryce, Kingdom of the Hittites, 302-303.

${ }^{92}$ H. Bahar, "Konya-Hatip'te Bulunan Yeni Bir Hitit Anıt1 Eine neues hethitischen Denkmal in Konya-Hatip," Arkeoloji ve Sanat 73 (1996): 2-8; A. Dinçol and B. Dinçol, "Hatip Anıtı'ndaki Hiyeroglif Yazıt," Arkeoloji ve Sanat 73 (1996): 8-9; H. Ehringhaus, "Kurunta als hethitischer Großkönig: Das großreichszeitliche Felsrelief von Hatip (Türkei)," Antike Welt 32/5 (2001): 518; Bonatz, "Divine Image of the King," 122-23; de Martino, "Symbols of Power," 91.
} 


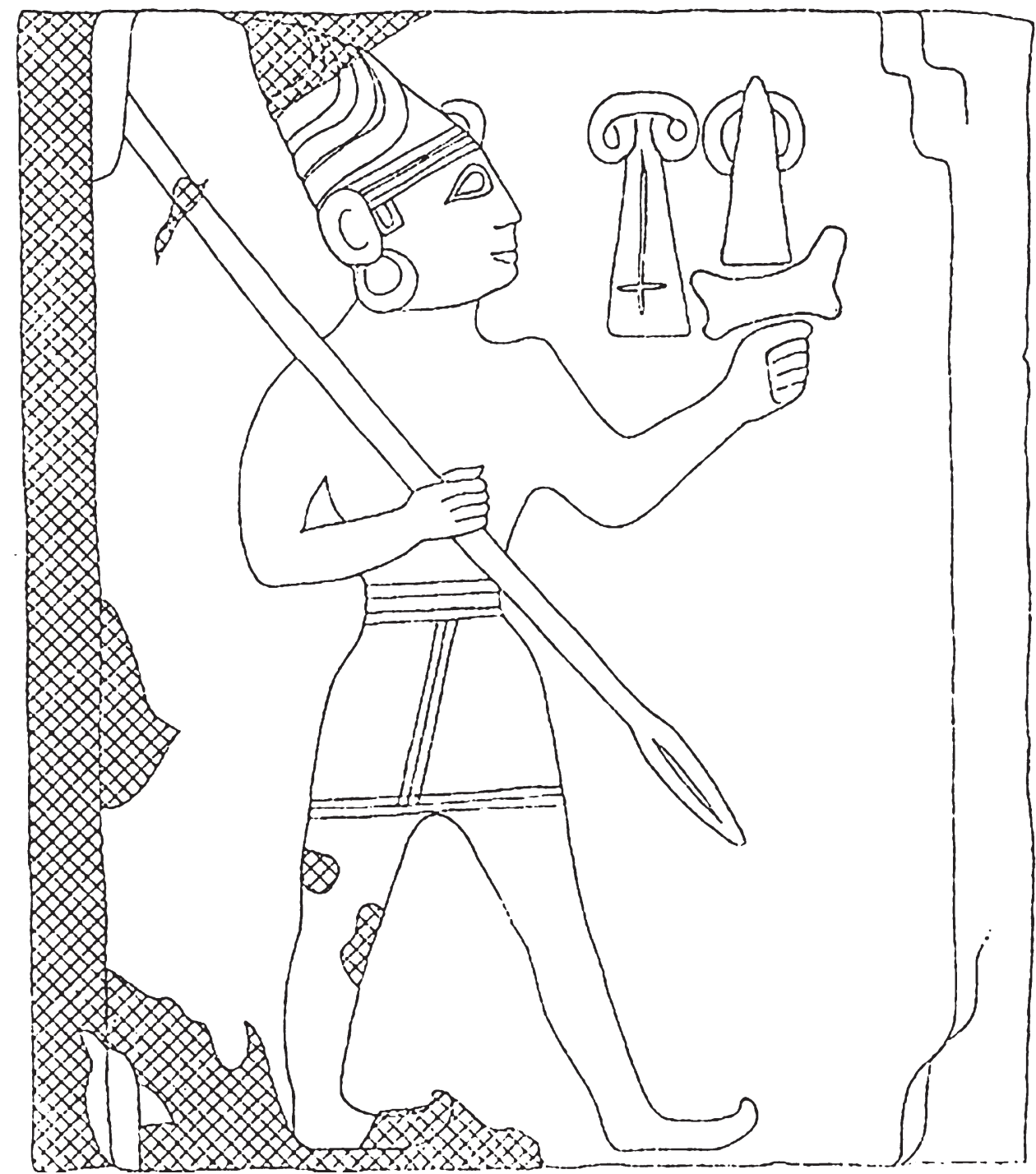

Figure 7-BOĞAZKÖY 19, depicting Tudhaliya (Neve, "Boğazköy-Ḩattuša. Ergebnisse der Ausgrabungen in der Oberstadt," 87). Image courtesy of NINO Publications.

"Labarna" and "My Sun" as his titles, suggest that Kurunta soon set his eyes on the throne of Hattuša and maybe even staged a coup, although there is no textual evidence to support this claim. ${ }^{93}$ Furthermore, Tudhaliya was also facing rebellions and threats from his western, southwestern, southeastern, and northern neighbors, as well as from Hattuša itself. ${ }^{94}$ In such a political climate, Tudhaliya IV's claim of divinity and the accompanying anthropomorphic imagery may find a specific correlation in the pressure he felt from the borderlands of the empire. In other words, the situa-

\footnotetext{
${ }_{93}$ Bryce, Kingdom of the Hittites, 319-20.

${ }^{94}$ Ibid, 299-323.
}

tion might have been so grim that visual imagery and discourse of service to the gods and being under their protection was not enough for Tudhaliya - he had to become a god himself.

\section{Implications of Royal Anthropomorphic Representations in Hittite Visual Media}

The observations pertaining to the three modes of representing the Hittite king in human form summarized above point to three important preliminary conclusions. First, anthropomorphic representations of the Hittite king constitute a small corpus, demonstrating that these royal images were a phenomenon of limited 


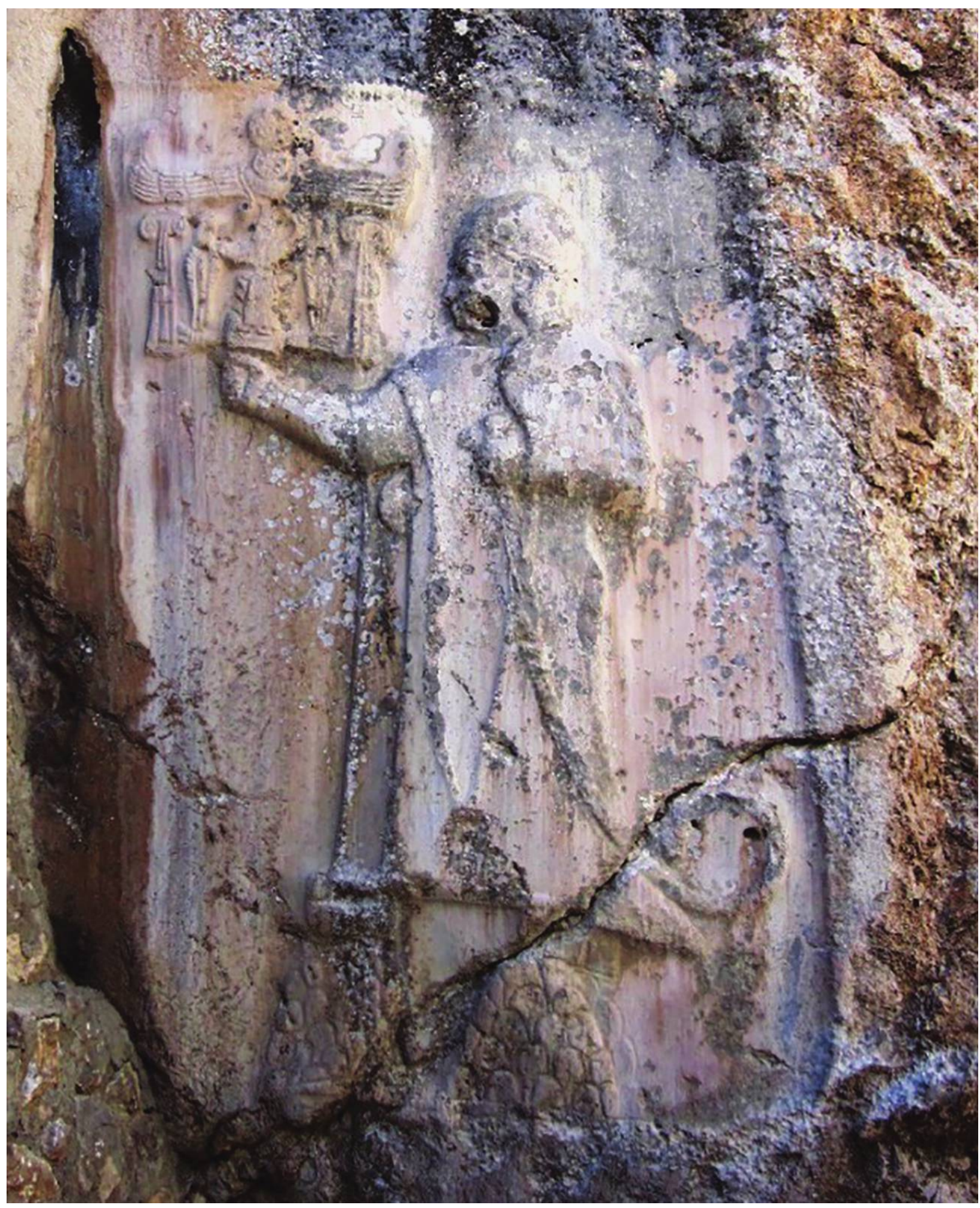

Figure 8-yAZILIKAYA 64, depicting Tudhaliya IV standing on two mountains in his ceremonial dress (photo by author). 
use and circulation. This is difficult to see as an accident of preservation, even with the possible addition of unpreserved royal statuary. In the case of rock reliefs, for instance, there are thirty-three sites throughout Anatolia and northern Syria with reliefs dating to the Late Bronze Age (see Fig. 2), with twenty-two of them bearing anthropomorphic representations, while only five of them can be securely identified as Hittite kings; the rest belong to gods, Hittite princes, officials, and local kings. ${ }^{95}$ Second, the reign of Muwatalli II (r. $1296-1273 \mathrm{BC}$ ) marks both the starting point ${ }^{96}$ and a particular acceleration for the bodily images of Hittite kings (see Table 1). He executed these images on two new media: rock reliefs, which were carved on living rock, as opposed to the orthostats previously used in the Hattuša's monuments; and seals. Finally, in each case, there is always a divine element in the scene. The king is either in the company of gods, or is a god himself.

The two final observations, that anthropomorphic images of the Hittite kings experience a peak at the start of the 13th century BC, and that they always carry a divine element, necessitate further discussion on two levels, political and ontological. On a political level, I read Muwatalli II's preference for these images as a specific response related to the urge to better control the borderlands of the empire. A particular motivation would be the eventual conflict with Egypt over the control of Syria, as well as the continued conflicts in the north and west of Anatolia, the combination of which led to Muwatalli II's relocation of the capital to Tarhuntassa. ${ }^{97}$ Why, however, would Muwatalli II deem it a good strategy to commission and circulate his anthropomorphic images as a tool of legitimacy? C. Glatz has demonstrated that Late Bronze Age rock reliefs in Anatolia, which have traditionally been treated as a monolithic and coherent "Hittite" corpus, indeed represent a varied patronage of local rulers and vassals of non-Hittite political entities in Anatolia, as well as Hittite princes and kings. ${ }^{98}$ The earliest examples of

\footnotetext{
95 This conclusion has been reached by reviewing the corpus and attestations as argued in: Kohlmeyer, "Felsbilder der Hethitischen Großreichzeit"; Ehringhaus, Götter, Herrscher, Inschriften: Die Felsreliefs der Hethitischen Großreichszeit in der Türkei, Glatz and Plourde, "Landscape Monuments and Political Competition in Late Bronze Age Anatolia"; and Harmanşah, Place, Memory, and Healing: An Archaeology of Anatolian Monuments.

${ }^{96}$ de Martino, "Symbols of Power," 87-89.

${ }^{97}$ Bryce, Kingdom of the Hittites, 230-33.

${ }^{98}$ C. Glatz, "Empire as Network: Spheres of Material Interaction in Late Bronze Age Anatolia," Journal of Anthropological Archaeology 28/2 (2009): 136; Glatz and Plourde, "Landscape
}

these monuments are the ones at IMAMKUlu, Hanyeri, Akpinar, and Suratkaya, none of which belong to a Hittite Great King. ${ }^{99}$ Prince $\mathrm{Ku}($ wa $)$ lanamuwa is depicted in martial attire, in the presence of the Storm God and Mountain Gods at Imamkulu ${ }^{100}$ and HaNyeri. ${ }^{101}$ In AKPINAR, a seated figure of a deity is carved into the bedrock of Mount Sipylus, attached with a hieroglyphic epithet again read as $\mathrm{Ku}$ (wa)lanamuwa. ${ }^{102}$ These reliefs were, thus, individualized claims to power commissioned by princes and local rulers in the border regions of the Hittite Empire. From this perspective, I suggest that carving landscape monuments and furnishing them with anthropomorphic images could have originally served the purpose of contesting the authority of the Hittite king by local rulers and vassal states already in regular opposition to the Hittite throne, rather than celebrating Hittite power. Adopting this technology then was an attempt on behalf of Muwatalli II to incorporate himself into this existing and already meaningful sphere of representation of power. In other words, carving living rock surfaces with rulers' images to communicate power was a true innovation of the borderlands, which was then adopted by Hittite kings.

The same can be argued for the glyptic evidence. Northern Mesopotamia had a tradition of royal figures venerating the gods, praying, or performing cultic duties on cylinder seals that goes back to the Late Uruk period. ${ }^{103}$ Thus, the interaction with the southeastern borderlands of the empire, I argue, resulted in the incorporation of the body of the Hittite king as

Monuments and Political Competition," 35; C. Glatz, "Places in the Political Landscape of Late Bronze Age Anatolia," in Of Rocks and Water: Towards an Archaeology of Place, ed. Ö. Harmanşah (Oxford, 2014), 130. See also S. Aro, "Art and Architecture," in The Luwians, HdO 86, ed. Melchert, 288 for an argument on Luwian origins of rock reliefs.

${ }^{99}$ Glatz and Plourde, "Landscape Monuments and Political Competition," 35, Table 2, 56; Goedegebuure, "Hittite Iconoclasm," 409; de Martino, "Symbols of Power," 93. This argument is based on the attestation of Kuwalana-muwa in the annals of Muršili II as demonstrated in J. D. Hawkins, "Kuwatna-muwa," Reallexikon der Assyriologie 6 (1980-1983), 398.

${ }^{100}$ Ehringhaus, Götter, Herrscher, Inschriften, 70-76.

${ }^{101}$ Ibid, 76-80.

${ }^{102}$ Ibid, 84-87.

${ }^{103}$ The examples are too numerous to cite here, but for an example from the end of the 4th millennium BC, see VA 11040 from the Vorderasiatische Museum: B. Salje, "Uruk and the World of Gilgamesh," in Art of the First Cities: The Third Millennium B.C. from the Mediterranean to the Indus, ed. J. Aruz (New York, 2003), 481 , fig. 110 . 
an emblem of kingship in correspondences. By this, the Hittite administration adopted a technology of signage and communication that was meaningful as a representation of the royal authority in the southeastern borderlands to more effectively govern these regions. This became even more important during the reign of Muwatalli II as he fought Egypt over the control of Syria, and might have resulted in the incorporation of a particular glyptic style to make himself look more amenable to the Syrian kingdoms. In this way, Muwatalli II might have meant to tell the local rulers in Syria that he was speaking their language, and was thus their rightful ruler in the face of the approaching Egyptian claim on the region.

On an ontological level, the close association of the bodily representation of the king with the divine was a programmatic attempt to enforce the idea of the king's close association with the divine realm as an individual, granting him the legitimacy to occupy the office of kingship. The anthropomorphic representations of the Hittite king thus served a specific set of purposes in which the relationship between the king and the divine realm was articulated, and the resulting royal authority was communicated. This articulation took place over centuries as its message got stronger. In the 13th century $\mathrm{BC}$, divine encounter scenes were mostly replaced by the embrace scenes illustrating the king under direct divine protection. Another interaction between the king and the divine was also communicated throughout the 14th and 13th centuries $\mathrm{BC}$ - his ability to become a god upon death, or maybe even in life. In contrast, when the kings wanted to emphasize a continuous office of kingship above individual identities, they preferred non-anthropomorphic illustrations making use of the hieroglyphic writing system. The graphic qualities of the hieroglyphic script enabled a wider dissemination of the royal message, as the signs for Great King (MAGNus.rex) would be familiar to a broad populace through repetition, and visible to many with the monuments and inscriptions located in the open landscape.

\section{Conclusions}

During the 14th and the 13th centuries BC, Hittite kings utilized hieroglyphic script on their seals to visually signify the office of kingship, while developing a distinct iconography of anthropomorphic representations depicting themselves in three different modes of engaging with the divine: facing a deity, being em- braced by a protective god, or the king portrayed as a god himself. The survey of the anthropomorphic representations of Hittite kings across a variety of media presents a consistently conservative pattern in terms of both the number of examples executed and the scenes depicted on them.

Above, I suggested that the difference between the anthropomorphic and the non-anthropomorphic representations of the Hittite king was a focus on the individual in the former, and a focus on the office of kingship in the latter. Marked by the exaggerated and repeated MAGNUS.REX signs in hieroglyphic Luwian, and flanking (in seals) or preceding (in inscriptions) the name of the individual king, the hieroglyphic signs for the office of kingship would immediately signify royal presence and patronage. Rooted in a uniquely Anatolian script, the MAGNUS.REX signs were able to overcome the limitations of literacy when used in monumental inscriptions, while marking Hittite kingship as connected to, yet different from greater Mesopotamia when used in conjunction with the cuneiform outer rings in seal impressions. Emphasizing the office above the individual painted a picture of continuity within a royal family often divided by feuds. Bypassing the instances and outcomes of cases of usurpation, rebellion, and even murder within the family, the consistent use of the MAGNUS.REX signs managed to communicate a continuous and stable office independent of the individuals occupying it. Yet in times of crisis during the empire period, the Hittite kings utilized a larger number of anthropomorphic images, both to take part in the administrative technologies of figural representations in the borderlands, and to emphasize their connection with the divine realm as individuals legitimately occupying the throne of Hattuša.

The media on which the anthropomorphic representations were predominantly used-rock reliefs and seals-suggest that the audience of these messages were mainly the borderlands of the empire. The monuments at SIRKELI and FRAKTIN were located at the southern edges of the empire, ${ }^{104}$ while the impressions

${ }^{104}$ While Fraktin and Sirkeli were located in areas of intense Hittite political control, especially during the 14th and 13th centuries $\mathrm{BC}$, the web of cultural interactions surrounding these monuments situate them as borderlands in the sense that I defined in $\mathrm{n} .22$ above. Fraktin is one of the four monument locales discovered so far in the Zamantı Su Valley. These monuments reflect varied patronages, sometimes synchronically. While İMAmKulu and HaNyeri A were commissioned by $\mathrm{Ku}($ wa)lanamuwa during the reign of Muršili I (cf. n. 101), FrakTIN depicts Hittite king Hattušili III and 
of the seals can be speculated to have circulated among the administrative elite of a much larger geography,

queen Puduhepa libating to deities half a century later (cf. n. 60). During the reign of Hattušili III, prince Tarhuntabiyammi also inscribed his power on rock monuments in the Zamantı Su Valley (cf. Kohlmeyer, "Felsbilder der Hethitischen Großreichzeit": 88-90, 92-94; Ehringhaus, Götter, Herrscher, Inschriften, 80, 108; Glatz and Plourde, "Landscape Monuments and Political Competition," 51-52; Harmanşah Place, Memory and Healing, 100-110). Local kings and princes thus continued to utilize rock monuments to take a political stand against the Hittite administration, turning this region into a complex borderland. SIRKELI contains a similar process with the relief of Muwatalli II in close proximity to another relief chiseled out in antiquity. These two reliefs can be read as marking the choice of one ancestor over another, or the erasing of local resistance by the Hittite imperial administration. In either case, they point to a complex net of power relationships as would be visible in complex borderlands. For a more detailed discussion, see Müge Durusu-Tanröver, Experiencing the Hittite Empire in Its Borderlands (Ph.D. diss., Brown University, 2016). including the empire, vassal kingdoms, and neighboring states.

The anthropomorphic representations of the Hittite kings thus constitute a small and distinctive corpus within the eastern Mediterranean, where the bodies of Neo-Assyrian kings or Egyptian pharaohs acted as emblems of kingship. By resorting to being represented in human form only in the presence of divine energy while using the hieroglyphic writing system to emphasize the office of kingship in other instances, the Hittite kings deliberately manipulated when and how they communicated their claims of power to different audiences. 